\title{
Application of Association Rule Method Using Apriori Algorithm to Find Sales Patterns Case Study of Indomaret Tanjung Anom
}

\author{
M. Hamdani Santoso ${ }^{1 *}$ \\ ${ }^{1}$ Universitas Medan Area, Indonesia \\ 1hamdanisantos123@gmail.com
}

open

access

\begin{tabular}{l} 
*Corresponding Author \\
\hline Article History: \\
Submitted: 08 Dec 2021 \\
Accepted: 15 Dec 2021 \\
Published: 15 Dec 2021 \\
\hline Keywords: \\
Data Mining; Association \\
Rule; Apriori; Sales Pattern; \\
RapidMiner.
\end{tabular}

\begin{abstract}
Brilliance: Research of Artificial Intelligence is licensed under a Creative Commons Attribution-NonCommercial 4.0 International (CC BY-NC 4.0).
\end{abstract}

\begin{abstract}
Data mining can generally be defined as a technique for finding patterns (extraction) or interesting information in large amounts of data that have meaning for decision support. One of the well-known and commonly used association rule discovery data mining methods is the Apriori algorithm. The Association Rule and the Apriori Algorithm are two very prominent algorithms for finding a number of frequently occurring sets of items from transaction data stored in databases. The calculation is done to determine the minimum value of support and minimum confidence that will produce the association rule. The association rule is used to produce the percentage of purchasing activity for an itemset within a certain period of time using the RapidMiner software. The results of the test using the priori algorithm method show that the association rule, that customers often buy toothpaste and detergents that have met the minimum confidence value. By searching for patterns using this a priori algorithm, it is hoped that the resulting information can improve further sales strategies.
\end{abstract}

\section{INTRODUCTION}

The development of information technology has contributed to the rapid growth in the amount of data collected and stored in large databases. This also brings major changes to the level of competition in companies, so companies and business actors must create various solutions to survive. So we need a method or technique that can turn a mountain of data into information or valuable knowledge useful to support business decision making. One technology that can be used to make it happen is data mining. Data Mining is the process of extracting information from data sets through the use of algorithms and techniques involving the fields of statistics, machine learning mathematics, artificial intelligence (Ridwan et al., 2013) and system management database (Yanto \& Khoiriah, 2015).

Management of very large data will involve the process of data mining. According to data mining is a procedure or stage in finding a data structure. Such data structures can take many forms, including rules, graphs or networks, trees and equations, and several others. Data mining is used for the extraction of important information hidden from big datasets. By using data mining a case can be seen from trends, structures and predictions in the future (Fatihatul et al., 2011). Data mining itself has many stages and techniques that can be applied in real life. Data mining is part of the process stages Knowledge Discovery in Database (KDD) (King et al., 1966). With data mining, we can classify, predict, estimate and get other useful information from large data sets (Mardi, 2017). 


\section{$\llbracket$ Brilliance}

The company's fierce competition in the field of sales makes business actors smart in analyzing the market. In addition, the availability of goods sold is also one of the factors that must be analyzed so that customer needs can be met. Therefore, many researchers are trying to change the current sales process patterns, especially in the trade sector. One of the companies engaged in buying and selling is a mini market (Indomaret). Indomaret is one of the minimarket networks in Indonesia that provides basic necessities and daily needs (Hasibuan et al., 2017) with a sales area of less than $200 \mathrm{M} 2$. This business began to grow when PT. Indomarco Prismatama first built Indomaret outlets in Jakarta in 1998, and then followed by building Indomaret outlets throughout Indonesia (Wahyuni, 2019).

So far, transactions that occur are only allowed to accumulate and become a data warehouse. There is no analysis of sales data regarding the pattern of customer purchases that should be, because the data can provide information or knowledge which is useful if handled properly. One of the efforts to explore information or added value from a data warehouse is often termed data mining (Al Syahdan $\&$ Sindar, 2018). The method that is often used to analyze customer buying patterns is the association method or association rule mining. Association rule mining is a method for finding the pattern of relationships between one or more itemsets in a dataset (Sornalakshmi et al., 2020).

Association Rule is a technique used to find out what processes often occur together. The Association Rule algorithm used is the a priori algorithm. A priori algorithm is a data retrieval algorithm with associative rules (associative rules) to determine the associative relationship of item combinations. The association rules in question are carried out through a mechanism for calculating support and confidence from the relationship of goods (Yanto \& Khoiriah, 2015). The process of searching for association rules or relationships between itemsets is obtained from a relational data base (Yudanar et al., 2020). In the retail business, the association rule mining method is more commonly known as a shopping basket (market basket analysis) (Gunadi \& Sensuse, 2012).

Market Basket Analysis is a method of analyzing consumer behavior specifically from a particular group/group (Gunadi \& Sensuse, 2012). The affinity analysis function or market basket analysis is a rule that states the association between several attributes. This Market Basket Analysis is considered capable of providing a way out in recommending a combination of product categories related to the use of the Apriori algorithm through the Association Rules method. The Apriori Algorithm was invented by Agrawal (Wang and Zheng 2020) and Srikant (Raj et al., 2020) 1994 (Yang et al., 2017).

So this study discusses the sales pattern of Indomaret, the case study of Indomaret Tanjung Anom using the Apriori Algorithm with association rules which aims to increase product sales by finding association rules from product purchase transactions. This algorithm will determine consumer buying patterns and then form a combination of items that are often sold to be used as sales packages or bundling. Provide data on products that are purchased by customers as data, so that it can be seen how many customers buy a product that is influenced by other products. In the end, it can make it easier to reference the stock of goods and automate the calculation of the analysis of goods sales at Indomaret Tanjung Anom.

\section{LITERATURE REVIEW}

\section{A. Data Mining}

The system that builds the classifier (Lindell \& Pinkas, 2000) is one of the tools commonly used in data mining. The system takes as input a collection of cases, each belonging to one of a small number of classes and described by their values for a fixed set of attributes, and generates a classifier that can accurately predict the class to which the new case belongs (Wu et al., 2008). According to 
(Ayyoubzadeh et al., 2020) Data mining algorithms and techniques are well-known tools for predictive model development and data analysis (Injadat et al., 2020). They can implicitly extract useful (Ge et al., 2017) information (Asif et al., 2017) from raw data (P. Liu et al., 2020). The extracted knowledge can be used in various fields. Data mining helps at this point by investigating unrelated relationships in the data and providing useful insights to data owners (Chamikara et al., 2020).

Meanwhile, according to (Hearst, 1999) data mining tends to be automated trending and up-todate across very large data sets, usually for decision-making purposes (Hearst, 1999). For this reason, the application of machine learning and data mining methods today is very important and indispensable in an effort to intelligently transform all available information into valuable knowledge (Kavakiotis et al., 2017). Recently, the term Big Data has become famous replacing data mining. This is a complete rebranding of the term data mining with a focus on ever larger and more diverse data sets and sources. In addition, such capabilities may often need to be shared with external parties for further analysis (Chamikara et al., 2020).

\section{B. Association Rule Mining}

In recent years, researchers have realized that association rule mining is one of the most effective algorithms for solving various problems (Zhang et al., 2019). Association rules are widely used in various fields such as, telecommunications networks, markets, human age risk and inventory control (Son et al., 2018). Mining association rules (Li \& Zhang, 2011) plays an important role in data mining and knowledge discovery as it can reveal strong associations between items in the database. There is, however, an important problem with traditional association rules. The mining method is that they can generate a very large number of association rules depending on how the parameters are set (Nguyen et al., 2018). Association rule mining basics introduced by Agrawal (Jeeva \& Rajsingh, 2016) 1993 (Schmitz et al., 2006), mining association issues have received a lot of attention.

Association rules of the form $\mathrm{A} \rightarrow \mathrm{B}$ where $\mathrm{A}$ (antecedent) and $\mathrm{B}$ (consequent) is a set of predicates (Abdel-Basset et al., 2018). A spatiotemporal association rule occurs when there is a spatiotemporal relationship in the antecedent or consequence of the rule. The basic model of association rules is as follows. Suppose $/=\left\{i j, i_{2}>\ldots, i m\right\}$ into a set of items. Let $\mathrm{T}$ be a set of transactions (database), where each transaction $\mathrm{t}$ (data case) is a set of items such that $t \underline{C Z} /$. The association rule is an implication of the form $X \rightarrow Y$, where $X c /, Y c I$, and $X n Y=O$. Rule $X \rightarrow Y$ holding in the transaction set (Agarwal et al., 2013) T with confidence (Li et al., 2016) c if c\% of transactions in $\mathrm{T}$ that support $\mathrm{X}$ also support $\mathrm{Y}$. The rules have support $i^{\prime}$ in $T$ if. \% $\%$ of transactions in T contains $<j Y$ (Lee et al., 2005).

Association rule mining is a data mining technique that can be used to find a number of rules or combinations of items or frequent itemsets. Regarding residence characteristics, some association rules were found through Apriori-based analysis (Li et al., 2019). Association rules, one of the most useful constructs in data mining (Feng et al., 2016). Association rules are generally represented in the form of IF-THEN which is easier for researchers to interpret and understand the results obtained (Borah \& Nath, 2018). Mined association rules are usually filtered first by three statistical indicators, namely support, confidence and lift ratio. Support is an indication of how often the association rule appears in the data set. Confidence is an indication of how reliable a rule calculation is. The lift ratio is an indication of the strength of the dependence between the antecedents and consequences of the association rule. Only association rules whose support, confidence and lift ratios are greater than the corresponding thresholds are left for further association rule analysis. For more details, see the equation below: (Schmitz et al., 2006) : 


$$
\begin{gathered}
\operatorname{support}(A \rightarrow B)=P(A \cup B) \\
\operatorname{confidence}(A \rightarrow B)=P(B \backslash A)=\frac{P(A \cup B)}{P(A) P(B)}(2) \\
\operatorname{lift}(A \rightarrow B)=\frac{P(A \cup B)}{P(A) P(B)}(3)
\end{gathered}
$$

where $P(A B)$ is the probability that $A$ and $B$ coincide in the data set to be analyzed, $P(B \mid A)$ is the conditional probability of $\mathrm{B}$ given $\mathrm{A}, \mathrm{P}(\mathrm{A})$ is the probability that $\mathrm{A}$ appears in the data set, and $\mathrm{P}(\mathrm{B})$ is the probability that $\mathrm{B}$ appears in the data set (Zhang et al., 2019).

\section{Apriori Algorithm}

The Apriori algorithm is one of the algorithms that is widely used in the discovery of association rules. The Apriori algorithm is considered to be the best known algorithm for mining (Liu et al., 2017) association rules used to find a common set of items (Azeez et al., 2019). This algorithm is also successfully applied in many fields such as, hypothesis, numerical investigation, big data processing, etc. Developed by Agrawal (Jeeva \& Rajsingh, 2016) and Sriknat (Raj et al., 2020). Although the performance of the classical Apriori algorithm using the iterative method (Yang et al., 2017) cannot compete with sophisticated depth-first approaches. Therefore the basic idea of finding all frequent items in a given database is universal and easy to apply to any rule asosiasi (Hong et al., 2020) mining problem though approach depth-first (Yuan, 2017).

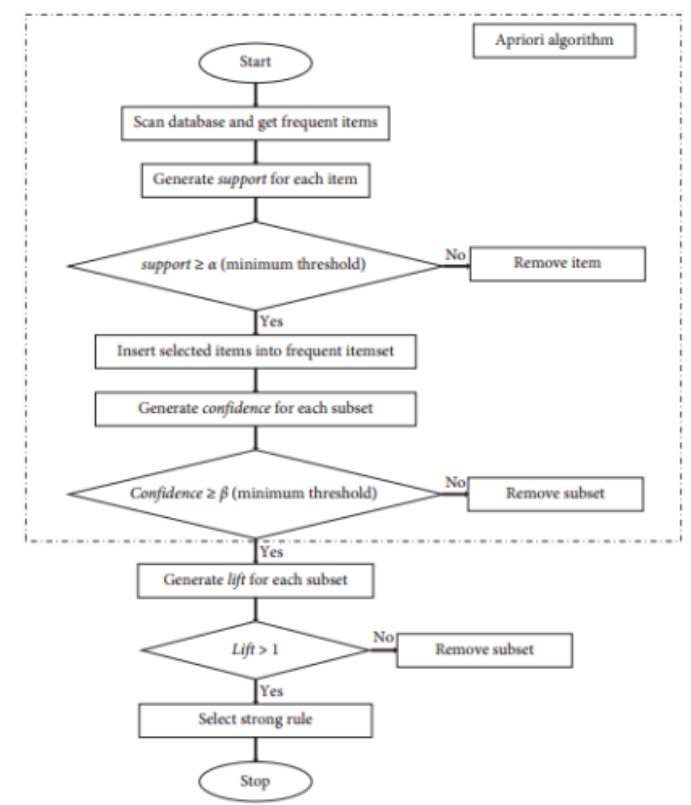

Fig 1. Association Rule Mining Process Flow Chart

There are two steps in using the Apriori algorithm for association rule mining. The first step is to find all the frequently occurring item sets from the database or data warehouse. The second step is to generate association rules from the set of frequently occurring items. The second step is easier to achieve, while the first step is difficult to achieve. Since the overall performance of mining association rules is decided by the first step, most studies are focused on the first problem (Guo et al., 2017). 


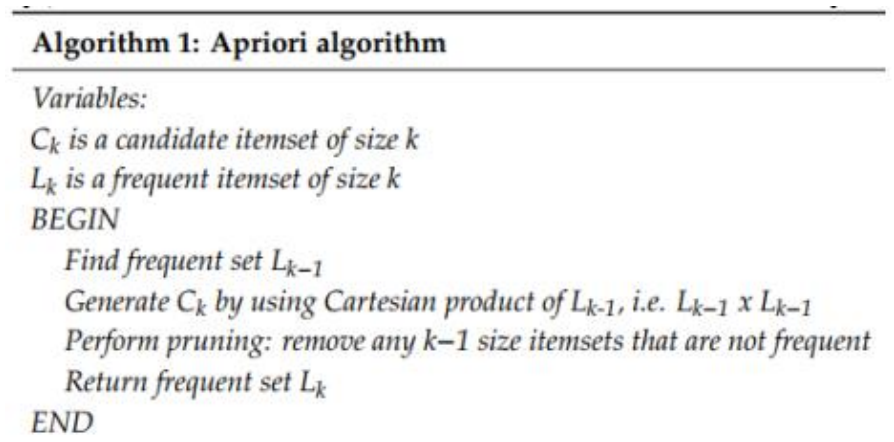

The Apriori algorithm is summarized in Algorithm 1. This algorithm has two stages: the training stage and the testing stage. In the training phase, the algorithm can observe the behavior specification and make generalizations from it. Some algorithms are set learning stages, where known attack samples are provided. In the testing phase, the algorithm is provided with the situation and decides on the possibility of having an attack. This algorithm uses an extensive search mechanism and hash tree configuration to make candidate itemsets computed efficiently to determine the frequency of occurrence for each itemsets. (Junianto \& Rachman, 2020). The pseudocode of the algorithm is summarized in Algorithm 2 (Azeez et al., 2019).

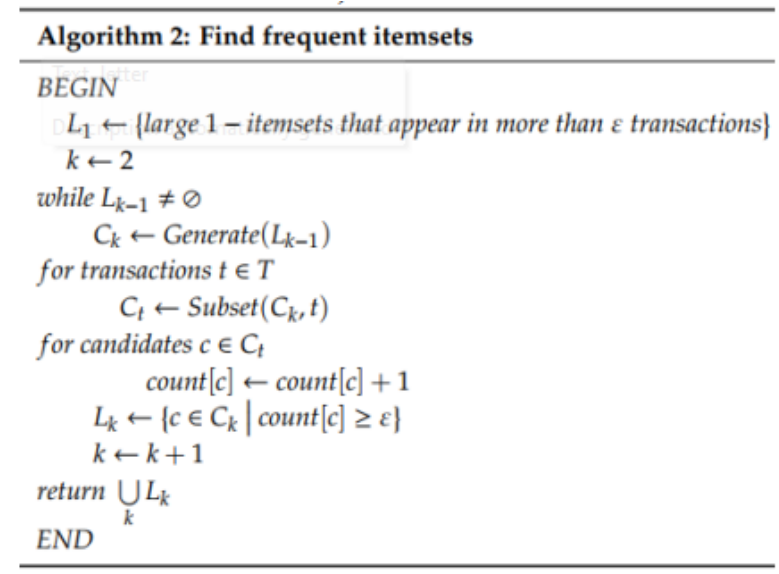

\section{RapidMiner}

Today, there are various well-known general purpose tools and frameworks that can be used for data mining purposes such as: Rapidminer, Weka, SPSS, Knime, Orange, Spark Lib, and so on. However, this tool is not easy for researchers to use because it is necessary to select a particular method/algorithm to apply or use and to provide appropriate parameters beforehand in order to get good results/models. So, researchers must have a certain amount of expertise to find the right setting (Romero \& Ventura, 2020). All data mining techniques in this study have been carried out with RapidMiner software.

Rapid Miner is a software created by Dr. Markus Hofmann from the Blanchardstown Institute of Technology and Ralf Klinkenberg from rapid-i.com with a GUI (Graphical User Interface) display making it easier for users to use this software. RapidMiner is open source software. RapidMiner is a solution to perform an analysis of data mining, text mining and predictive analysis. By using Rapid Miner, no special coding skills are needed, because all the features are provided. RapidMiner has approximately 500 data mining operators, including operators for input, output, data preprocessing 
and visualization (Rahmatullah et al., 2020).

\section{METHOD}

\section{A. Dataset}

The dataset used in this study was taken from surveys, observations and direct interviews. The data sample consists of several transaction records totaling 16 purchase transactions.

\section{B. Research Steps}

The research steps modeled in this study are illustrated in figure 2.

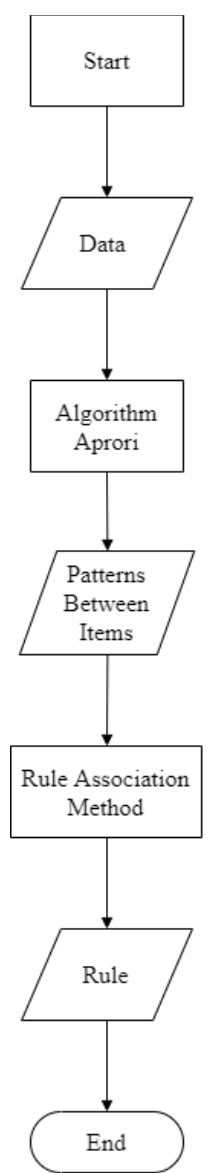

Fig 2. Research Steps

Figure 2 shows the research steps to be carried out by entering the sample data to be studied, then the Apriori Algorithm functions to determine the classification of patterns/combinations in a set of itemsets. Then the Association Rule method is used to process the data and calculate the results of the association rules on that set of items.

\section{RESULT}

\section{A. Transaction Data Sample}

The sample data used in this study were taken from surveys and field observations. Table 1 below attaches a sample of purchase transaction data. 
Table 1. Purchase Transaction Sample Data

\begin{tabular}{|r|c|}
\hline \multicolumn{1}{l|}{ ID } \\
TRX \\
\hline 1 & ITEM SET \\
\hline 2 & Snack, Soft Drink, Cigarette, Face Wash, Tissue \\
\hline 3 & Snack, Ice Cream, Toothpaste, Bath Soap, Tissue \\
\hline 4 & Ice Cream, Tissue \\
\hline 5 & Snack, Cigarette, Toothpaste, Face Wash, Detergent, Bath Soap \\
\hline 6 & Soft Drink, Detergent, Bath Soap, Tissue, Baby Diapers \\
\hline 7 & Snack, Soft Drink, Toothpaste, Face Wash, Bath Soap, Baby Diapers \\
\hline 8 & Snack, Cigarette, Toothpaste, Detergent, Bath Soap \\
\hline 10 & Soft Drink, Face Wash \\
\hline 11 & Toothpaste, Face Wash, Detergent, Bath Soap \\
\hline 12 & Bath Soap, Baby Diapers \\
\hline 13 & Face Wash \\
\hline 14 & Snack, Face Wash \\
\hline 15 & Toothpaste, Face Wash, Detergent, Bath Soap, Tissue, Baby Diapers \\
\hline 16 & \\
\hline
\end{tabular}

B. Implementation and Testing

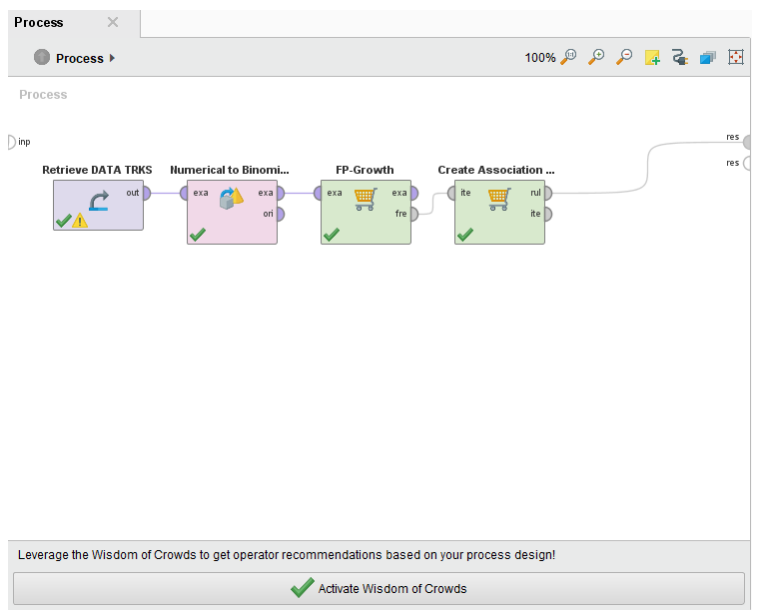

Fig 3. Design Process on RapidMiner

Figure 3 above shows the design design of the purchase transaction data to be studied using RapidMiner software. After everything has been configured between the data and the algorithm you want to use, then run the process. This study uses the provisions of min. support $70 \%$ and $\mathrm{min} .70 \%$ confidence. 
Based on table 2 below, the results of the calculation of support and confidence that have been described in the previous sub-chapter, obtained 22 association rules where all confidence values have met the minimum value, from this information it can be concluded that the purchasing pattern and product combination rule can be seen in table 3 .

Table 2. Results of Lift Ratio Association Rule

\begin{tabular}{|c|c|c|c|c|c|c|c|}
\hline No. & Itemset & Conclusion & Support & Confidence & Laplace & Gain & $\mathrm{P}-\mathrm{S}$ \\
\hline 8 & $\begin{array}{l}\text { Face Wash, Bath Soap, } \\
\text { Toothpaste }\end{array}$ & Detergent & 0.2 & 0.75 & 0.947368421 & -0.333333333 & 0.075555556 \\
\hline 9 & Face Wash, Bath Soap, Detergent & Toothpaste & 0.2 & 0.75 & 0.947368421 & -0.333333333 & 0.075555556 \\
\hline 10 & $\begin{array}{l}\text { Face Wash, Toothpaste, } \\
\text { Detergent }\end{array}$ & Bath Soap & 0.2 & 0.75 & 0.947368421 & -0.333333333 & 0.04 \\
\hline 11 & Bath Soap, Toothpaste, Detergent & Face Wash & 0.2 & 0.75 & 0.947368421 & -0.333333333 & 0.022222222 \\
\hline 12 & Soft drink & Face Wash & 0.2666666667 & 0.8 & 0.95 & -0.4 & 0.044444444 \\
\hline 13 & Baby Diapers & Bath Soap & 0.266666667 & 0.8 & 0.95 & -0.4 & 0.066666667 \\
\hline 14 & Face Wash, Bath Soap & Toothpaste & 0.266666667 & 0.8 & 0.95 & -0.4 & 0.111111111 \\
\hline 15 & Face Wash, Toothpaste & Bath Soap & 0.266666667 & 0.8 & 0.95 & -0.4 & 0.066666667 \\
\hline 16 & Face Wash, Bath Soap & Detergent & 0.2666666667 & 0.8 & 0.95 & -0.4 & 0.111111111 \\
\hline 17 & Face Wash, Detergent & Bath Soap & 0.2666666667 & 0.8 & 0.95 & -0.4 & 0.0666666667 \\
\hline 18 & Face Wash, Toothpaste & Detergent & 0.266666667 & 0.8 & 0.95 & -0.4 & 0.111111111 \\
\hline 19 & Face Wash, Detergent & Toothpaste & 0.2666666667 & 0.8 & 0.95 & -0.4 & 0.111111111 \\
\hline 20 & Toothpaste, Detergent & Face Wash & 0.2666666667 & 0.8 & 0.95 & -0.4 & 0.044444444 \\
\hline 21 & Snack, Toothpaste & Bath Soap & 0.266666667 & 0.8 & 0.95 & -0.4 & 0.066666667 \\
\hline 22 & Toothpaste, Detergent & Bath Soap & 0.266666667 & 0.8 & 0.95 & -0.4 & 0.066666667 \\
\hline 23 & Toothpaste & Bath Soap & 0.4 & 0.857142857 & 0.954545455 & -0.533333333 & 0.12 \\
\hline 24 & Detergent & Bath Soap & 0.4 & 0.857142857 & 0.954545455 & -0.533333333 & 0.12 \\
\hline 25 & Cigarette & Snack & 0.2 & 1 & 1 & -0.2 & 0.1066666667 \\
\hline 26 & Face Wash, Baby Diapers & Toothpaste & 0.2 & 1 & 1 & -0.2 & 0.106666667 \\
\hline 27 & Toothpaste, Baby Diapers & Face Wash & 0.2 & 1 & 1 & -0.2 & 0.066666667 \\
\hline 28 & Bath Soap, Snack & Toothpaste & 0.266666667 & 1 & 1 & -0.266666667 & 0.142222222 \\
\hline 29 & Bath Soap, Snack & Toothpaste & 0.2 & 1 & 1 & -0.2 & 0.106666667 \\
\hline
\end{tabular}

Table 3. Result of Association Rule

\begin{tabular}{|l|l|}
\hline No. & Association Rules \\
\hline & $\begin{array}{l}\text { IF Face Wash, Bath Soap, } \\
\text { Toothpaste, THEN Detergent }\end{array}$ \\
\hline 2 & $\begin{array}{l}\text { IF Face Wash, Bath Soap, } \\
\text { Detergent, THEN Toothpaste }\end{array}$ \\
\hline 3 & $\begin{array}{l}\text { IF Face Wash, Toothpaste, } \\
\text { Detergent, THEN Bath Soap }\end{array}$ \\
\hline 4 & $\begin{array}{l}\text { IF Bath Soap, Toothpaste, } \\
\text { Detergent, THEN Face Wash }\end{array}$ \\
\hline 6 & IF Soft Drink, THEN Face Wash \\
\hline 7 & $\begin{array}{l}\text { IF Baby Diapers, THEN Bath Soap } \\
\text { THEN Toothpaste }\end{array}$ \\
\hline 8 & IF Face Wash and Toothpaste, \\
\hline
\end{tabular}




\begin{tabular}{|l|l|} 
& THEN Bath Soap \\
\hline 9 & $\begin{array}{l}\text { IF Face Wash and Bath Soap, } \\
\text { THEN Detergent }\end{array}$ \\
\hline 10 & $\begin{array}{l}\text { IF Face Wash and Detergent, } \\
\text { THEN Bath Soap }\end{array}$ \\
\hline 11 & $\begin{array}{l}\text { IF Face Wash and Toothpaste, } \\
\text { THEN Detergent }\end{array}$ \\
\hline 12 & $\begin{array}{l}\text { IF Face Wash and Detergent, } \\
\text { THEN Toothpaste }\end{array}$ \\
\hline 13 & $\begin{array}{l}\text { IF Toothpaste and Detergent, } \\
\text { THEN Face Wash }\end{array}$ \\
\hline 14 & $\begin{array}{l}\text { IF Snack and Toothpaste, THEN } \\
\text { Bath Soap }\end{array}$ \\
\hline 15 & $\begin{array}{l}\text { IF Toothpaste and Detergent, } \\
\text { THEN Bath Soap }\end{array}$ \\
\hline 16 & IF Toothpaste, THEN Bath Soap \\
\hline 17 & IF Detergent, THEN Bath Soap \\
\hline 18 & IF Cigarette, THEN Snack \\
\hline 19 & $\begin{array}{l}\text { IF Face Wash and Baby Diapers, } \\
\text { THEN Toothpaste }\end{array}$ \\
\hline 20 & $\begin{array}{l}\text { IF Toothpaste and Baby Diapers, } \\
\text { THEN Face Wash }\end{array}$ \\
\hline 21 & $\begin{array}{l}\text { IF Bath Soap and Snack, THEN } \\
\text { Toothpaste }\end{array}$ \\
\hline 22 & $\begin{array}{l}\text { IF Snack and Detergent, THEN } \\
\text { Toothpaste }\end{array}$ \\
\hline
\end{tabular}

\section{DISCUSSION}

From the results of observations of data on a number of components of product sales transactions that occurred at Indomaret Tanjung Anom, 22 attributes of different association rules have been found between one algorithm and another. Research using the Apriori algorithm also produces 26 lift ratio association rules on the sales attributes of these products. The analysis conducted on the strength level of association rules shows that the association rules generated by the Apriori algorithm have a higher level of strength than those generated by the FP-growth algorithm.

\section{CONCLUSION}

Based on the research and discussion conducted, it can be concluded several things, namely the association rule mining method using a priori algorithms can be applied to find patterns of purchase transactions by combining goods used as sales packages or bundling in order to increase product sales. Based on the 22 association rules obtained, it produces 2 products that are often purchased at the same time, namely toothpaste and detergent with a support value of $40 \%$ and $80 \%$ confidence. The higher the minimum support and minimum confidence used, the fewer frequent itemsets and rules are formed and the accuracy decreases. The product combination rules have been found using 
association rules and have been tested using rapidminer software. Association rules can be applied to make it easier to reference stock of goods and automate the calculation of goods sales analysis at Indomaret Tanjung Anom.

\section{REFERENCES}

Abdel-Basset, M., Mohamed, M., Smarandache, F., \& Chang, V. (2018). Neutrosophic association rule mining algorithm for big data analysis. Symmetry, 10(4), 1-19. https://doi.org/10.3390/sym10040106

Agarwal, B. R., Srikant, R., \& Ahmad, M. A. (2013). Fast Algorithms For Mining Association Rules In Datamining. International Journal of Scientific \& Technology Research, 2(12), 13-24.

Al Syahdan, S., \& Sindar, A. (2018). Data mining penjualan produk dengan metode apriori pada Indomaret Galang Kota. Jurnal Nasional Komputasi Dan Teknologi Informasi (JNKTI), 1(2).

Asif, R., Merceron, A., Ali, S. A., \& Haider, N. G. (2017). Analyzing undergraduate students' performance using educational data mining. Computers and Education, 113, 177-194. https://doi.org/10.1016/j.compedu.2017.05.007

Ayyoubzadeh, S. M., Ayyoubzadeh, S. M., Zahedi, H., Ahmadi, M., \& R Niakan Kalhori, S. (2020). Predicting COVID-19 Incidence Through Analysis of Google Trends Data in Iran: Data Mining and Deep Learning Pilot Study. JMIR Public Health and Surveillance, 6(2), e18828. https://doi.org/10.2196/18828

Azeez, N. A., Ayemobola, T. J., Misra, S., Maskeliūnas, R., \& Damaševičius, R. (2019). Network intrusion detection with a hashing based apriori algorithm using Hadoop MapReduce. Computers, 8(4). https://doi.org/10.3390/computers8040086

Borah, A., \& Nath, B. (2018). Identifying risk factors for adverse diseases using dynamic rare association rule mining. Expert Systems with Applications, 113, 233-263. https://doi.org/10.1016/j.eswa.2018.07.010

Chamikara, M. A. P., Bertok, P., Liu, D., Camtepe, S., \& Khalil, I. (2020). Efficient privacy preservation of big data for accurate data mining. Information Sciences, 527(xxxx), 420-443. https://doi.org/10.1016/j.ins.2019.05.053

Fatihatul, F., Setiawan, A., \& Rosadi, R. (2011). Asosiasi Data Mining Menggunakan Algoritma FPGrowth Untuk Market Basket Analysis. Jatinangor: Universitas Padjadjaran, 1-8.

Feng, F., Cho, J., Pedrycz, W., Fujita, H., \& Herawan, T. (2016). Soft set based association rule mining. Knowledge-Based Systems, 111, 268-282. https://doi.org/10.1016/j.knosys.2016.08.020

Ge, Z., Song, Z., Ding, S. X., \& Huang, B. (2017). Data Mining and Analytics in the Process Industry: The Role of Machine Learning. IEEE Access, 5, 20590-20616. https://doi.org/10.1109/ACCESS.2017.2756872

Gunadi, G., \& Sensuse, D. I. (2012). Penerapan Metode Data Mining Market Basket Analysis Terhadap Data Penjualan Produk Buku Dengan Menggunakan Algoritma Apriori Dan Frequent Pattern Growth ( Fp-Growth ) : Telematika, 4(1), 118-132.

Guo, Y., Wang, M., \& Li, X. (2017). Application of an improved Apriori algorithm in a mobile ecommerce recommendation system. Industrial Management and Data Systems, 117(2), 287303. https://doi.org/10.1108/IMDS-03-2016-0094

Hasibuan, N. A., Silalahi, N., Nasution, S. D., Sutiksno, D. U., Nurdiyanto, H., Buulolo, E., Ambon, P. N., Pendahuluan, I., \& Mining, A. D. (2017). Implementasi Data Mining Untuk Pengaturan Layout. 4(4), 6-11.

Hearst, M. A. (1999). Untangling text data mining. 3-10. https://doi.org/10.3115/1034678.1034679 
Hong, J., Tamakloe, R., \& Park, D. (2020). Discovering Insightful Rules among Truck Crash Characteristics using Apriori Algorithm. Journal of Advanced Transportation, 2020. https://doi.org/10.1155/2020/4323816

Kavakiotis, I., Tsave, O., Salifoglou, A., Maglaveras, N., Vlahavas, I.P., \& Chouvarda, I. (2017). Machine Learning and Data Mining Methods in Diabetes Research. Computational and Structural Biotechnology Journal, 15, 104 - 116.

Injadat, M. N., Moubayed, A., Nassif, A. B., \& Shami, A. (2020). Systematic ensemble model selection approach for educational data mining. Knowledge-Based Systems, 200, 105992. https://doi.org/10.1016/j.knosys.2020.105992

Jeeva, S. C., \& Rajsingh, E. B. (2016). Intelligent phishing url detection using association rule mining. Human-Centric Computing and Information Sciences, 6(1). https://doi.org/10.1186/s13673016-0064-3

Junianto, E., \& Rachman, R. (2020). Penerapan Data Mining Metode Apriori Dan FP-Tree pada Penjualan Media Edukasi (Studi Kasus: Oisha Smartkids). IJCIT (Indonesian Journal on Computer and Information Technology), 5(2).

King, D. G., Young, W. E. V., Clarke, A. J., Cain, A. J., \& Dimbleby, G. W. (1966). The Lanhill Long Barrow, Wiltshire, England: An Essay in Reconstruction. Proceedings of the Prehistoric Society, 32, 73-85. https://doi.org/10.1017/S0079497X00014341

Lee, Y. C., Hong, T. P., \& Lin, W. Y. (2005). Mining association rules with multiple minimum supports using maximum constraints. International Journal of Approximate Reasoning, 40(1-2), 44-54. https://doi.org/10.1016/j.ijar.2004.11.006

Li, K., Liu, L., Wang, F., Wang, T., Duić, N., Shafie-khah, M., \& Catalão, J. P. S. (2019). Impact factors analysis on the probability characterized effects of time of use demand response tariffs using association rule mining method. Energy Conversion and Management, 197(July). https://doi.org/10.1016/j.enconman.2019.111891

Li, L., Lu, R., Choo, K. K. R., Datta, A., \& Shao, J. (2016). Privacy-Preserving-Outsourced Association Rule Mining on Vertically Partitioned Databases. IEEE Transactions on Information Forensics and Security, 11(8), 1847-1861. https://doi.org/10.1109/TIFS.2016.2561241

Li, L., \& Zhang, M. (2011). The strategy of mining association rule based on cloud computing. Proceedings of the 2011 International Conference on Business Computing and Global Informatization, BCGIn 2011, 475-478. https://doi.org/10.1109/BCGIn.2011.125

Lindell, Y., \& Pinkas, B. (2000). Privacy preserving data mining. Lecture Notes in Computer Science (Including Subseries Lecture Notes in Artificial Intelligence and Lecture Notes in Bioinformatics), 1880, 36-54. https://doi.org/10.1007/3-540-44598-6_3

Liu, P., Qingqing, W., \& Liu, W. (2020). Enterprise human resource management platform based on FPGA and data mining. Microprocessors and Microsystems, 103330. https://doi.org/10.1016/j.micpro.2020.103330

Liu, X., Zhao, Y., \& Sun, M. (2017). An Improved Apriori Algorithm Based on an EvolutionCommunication Tissue-Like P System with Promoters and Inhibitors. Discrete Dynamics in Nature and Society, 2017. https://doi.org/10.1155/2017/6978146

Mardi, Y. (2017). Data Mining: Klasifikasi Menggunakan Algoritma C4.5. Jurnal Edik Informatika, 2(2), 213-219.

Nguyen, L. T. T., Vo, B., Nguyen, L. T. T., Fournier-Viger, P., \& Selamat, A. (2018). ETARM: an efficient top-k association rule mining algorithm. Applied Intelligence, 48(5), 1148-1160. https://doi.org/10.1007/s10489-017-1047-4

Raj, S., Ramesh, D., Sreenu, M., \& Sethi, K. K. (2020). EAFIM: efficient apriori-based frequent 
itemset mining algorithm on Spark for big transactional data. Knowledge and Information Systems, 62(9), 3565-3583. https://doi.org/10.1007/s10115-020-01464-1

Ridwan, M., Suyono, H., \& Sarosa, M. (2013). Penerapan Data Mining Untuk Evaluasi Kinerja Akademik Mahasiswa Menggunakan Algoritma Naive Bayes Classifier. Jurnal EECCIS, 7(1), pp.59-64.

Romero, C., \& Ventura, S. (2020). Educational data mining and learning analytics: An updated survey. Wiley Interdisciplinary Reviews: Data Mining and Knowledge Discovery, 10(3), 1-21. https://doi.org/10.1002/widm.1355

Rustam, R., Rahmatullah, S., Supriyato, S., \& Wahyuni, S. (2020). Penerapan Data Mining Untuk Prediksi Penjualan Produk Triplek Pada Pt Puncak Menara Hijau Mas. Jurnal Informasi dan Komputer, 8(2), 75-86.

Schmitz, C., Hotho, A., Jäschke, R., \& Stumme, G. (2006). Mining Association Rules in Folksonomies. Data Science and Classification, 261-270. https://doi.org/10.1007/3-540-344160_28

Son, L. H., Chiclana, F., Kumar, R., Mittal, M., Khari, M., Chatterjee, J. M., \& Baik, S. W. (2018). ARM-AMO: An efficient association rule mining algorithm based on animal migration optimization. Knowledge-Based Systems, 154(September 2017), 68-80. https://doi.org/10.1016/j.knosys.2018.04.038

Sornalakshmi, M., Balamurali, S., Venkatesulu, M., Navaneetha Krishnan, M., Ramasamy, L. K., Kadry, S., Manogaran, G., Hsu, C. H., \& Muthu, B. A. (2020). Hybrid method for mining rules based on enhanced Apriori algorithm with sequential minimal optimization in healthcare industry. Neural Computing and Applications, 2. https://doi.org/10.1007/s00521-020-04862-2

Wahyuni, R. (2019). Prosedur Pelayanan Terhadap Kepuasan Pelanggan Pada Indomaret Tugu Cimanggis. Abiwara: Jurnal Vokasi Administrasi Bisnis, 1(1), 18-27. https://doi.org/10.31334/abiwara.v1i1.498

Wang, C., \& Zheng, X. (2020). Application of improved time series Apriori algorithm by frequent itemsets in association rule data mining based on temporal constraint. Evolutionary Intelligence, 13(1), 39-49. https://doi.org/10.1007/s12065-019-00234-5

Wu, X., Kumar, V., Ross, Q. J., Ghosh, J., Yang, Q., Motoda, H., McLachlan, G. J., Ng, A., Liu, B., Yu, P. S., Zhou, Z. H., Steinbach, M., Hand, D. J., \& Steinberg, D. (2008). Top 10 algorithms in data mining. In Knowledge and Information Systems (Vol. 14, Issue 1). https://doi.org/10.1007/s10115-007-0114-2

Yang, J., Huang, H., \& Jin, X. (2017). Mining web access sequence with improved apriori algorithm. Proceedings - 2017 IEEE International Conference on Computational Science and Engineering and IEEE/IFIP International Conference on Embedded and Ubiquitous Computing, CSE and EUC 2017, 1, 780-784. https://doi.org/10.1109/CSE-EUC.2017.154

Yanto, R., \& Khoiriah, R. (2015). Implementasi Data Mining dengan Metode Algoritma Apriori dalam Menentukan Pola Pembelian Obat. Creative Information Technology Journal, 2(2), 102. https://doi.org/10.24076/citec.2015v2i2.41

Yudanar, A. F., Fitriasih, S. H., \& Hasbi, M. (2020). Rekomendasi Barang Di Toko Elektrik Menggunakan Algoritma Apriori. Jurnal Teknologi Informasi Dan Komunikasi (TIKomSiN), 8(2). https://doi.org/10.30646/tikomsin.v8i2.499

Zhang, C., Xue, X., Zhao, Y., Zhang, X., \& Li, T. (2019). An improved association rule mining-based method for revealing operational problems of building heating, ventilation and air conditioning $\begin{array}{llll}\text { (HVAC) } & \text { systems. } & \text { Applied } & \text { Energy, }\end{array}$ https://doi.org/10.1016/j.apenergy.2019.113492 
Volume 1, Number 2, November 2021 https://doi.org/10.47709/brilliance.v1i2.1228 